\title{
Grain size, morphometry and mineralogy of airborne input in the Canary basin: evidence of iron particle retention in the mixed layer
}

\author{
Alfredo Jaramillo-Vélez ${ }^{1}$, Inmaculada Menéndez ${ }^{2}$, Ignacio Alonso ${ }^{2}$, José Mangas ${ }^{2}$, \\ Santiago Hernández-León ${ }^{2}$ \\ ${ }^{1}$ Grupo de Estudios Oceánicos "Luis Fernando Vásquez-Bedoya" (GEOc), Escuela Ambiental, Facultad de Ingeniería, \\ Universidad de Antioquía UdeA, Calle 70 No. 52-21, Medellín, Colombia. E-mail: alfredo.jaramillov@udea.edu.co \\ ${ }^{2}$ Instituto de Oceanografía y Cambio Global, IOCAG, Universidad de Las Palmas de Gran Canaria, ULPGC, Campus de \\ Taliarte, 35214 Telde, Gran Canaria, Spain.
}

\begin{abstract}
Summary: Aeolian dust plays an important role in climate and ocean processes. Particularly, Saharan dust deposition is of importance in the Canary Current due to its content of iron minerals, which are fertilizers of the ocean. In this work, dust particles are characterized mainly by granulometry, morphometry and mineralogy, using image processing and scanning northern Mauritania and the Western Sahara. The concentration of terrigenous material was measured in three environments: the atmosphere ( $300 \mathrm{~m}$ above sea level), the mixed layer at $10 \mathrm{~m}$ depth, and $150 \mathrm{~m}$ depth. Samples were collected before and during the dust events, thus allowing the effect of Saharan dust inputs in the water column to be assessed. The dominant grain size was coarse silt. Dominant minerals were iron oxy-hydroxides, silicates and $\mathrm{Ca}-\mathrm{Mg}$ carbonates. A relative increase of iron mineral particles (hematite and goethite) was detected in the mixed layer, reflecting a higher permanence of iron in the water column despite the greater relative density of these minerals in comparison with the other minerals. This higher iron particle permanence does not appear to be explained by physical processes. The retention of this metal by colloids or microorganisms is suggested to explain its long residence time in the mixed layer.
\end{abstract}

Keywords: textural analysis; Saharan dust; iron particles; Canary Islands.

Granulometría, morfometría y mineralogía de polvo atmosférico que entra a la cuenca canaria: evidencia de retención de partículas de hierro en la capa de mezcla

Resumen: El polvo atmosférico juega un papel importante en el clima y en los procesos oceánicos, particularmente la deposición del polvo sahariano es de suma importancia en la corriente canaria debido a que contiene minerales de hierro que actúan como fertilizante del océano. En este trabajo las partículas de polvo fueron caracterizadas mediante granulometría, morfometría y mineralogía, usando procesamiento de imágenes, microscopia electrónica (SEM-EDS). El polvo analizado en este estudio fue generado al norte de Mauritania y Sahara Occidental. Su concentración fue medida en tres ambientes diferentes: la atmósfera (300 m.s.n.m.), la capa de mezcla ( $10 \mathrm{~m}$ de profundidad) y a $150 \mathrm{~m}$ de profundidad). Las muestras fueron colectadas antes y durante los eventos de polvo, permitiendo la determinación del efecto del aporte de polvo sahariano a la columna de agua. El tamaño de grano predominante fueron los limos gruesos. Los minerales dominantes fueron oxihidróxidos, silicatos y carbonatos. Un incremento de partículas ricas en hierro (hematita y goetita) fue detectado en la capa de mezcla, reflejando una alta permanencia del hierro en la columna de agua a pesar de la alta densidad que presentan esos minerales con respecto a otros. Esta alta permanencia de hierro no parece ser explicada por procesos físicos. La retención de este metal por coloides o microrganismos es la explicación sugerida ante el alto tiempo de residencia en la capa de mezcla.

Palabras clave: análisis textural; polvo sahariano; partículas de hierro; Islas Canarias.

Citation/Como citar este artículo: Jaramillo-Vélez A., Menéndez I., Alonso I., Mangas J., Hernández-León S. 2016. Grain size, morphometry and mineralogy of airborne input in the Canary basin: evidence of iron particle retention in the mixed layer. Sci. Mar. 80(3): 395-408. doi: http://dx.doi.org/10.3989/scimar.04344.27A

Editor: P. Puig.

Received: September 1, 2015. Accepted: April 11, 2016. Published: July 6, 2016.

Copyright: (C) 2016 CSIC. This is an open-access article distributed under the terms of the Creative Commons Attribution (CC-by) Spain 3.0 License. 


\section{INTRODUCTION}

Dust plumes are the main atmospheric transport process of fine-grained eolian material from deserts to the oceans. They are generated in specific source areas of the Sahara desert, and they can be transported over thousands of kilometres through the Atlantic Ocean, following the pathway of the Trade Winds and the Saharan Air Layer, and can even reach the Caribbean Sea in about 5-7 days (Prospero and Carlson 1980). This transport of particulate material affects many atmospheric processes, including cloud formation, radiation balance (Brust and Waniek 2010), biogeochemical processes (Iwamoto et al. 2011) and human health (Delgado 2010). The global dust production is estimat-

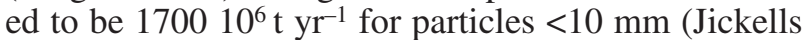
et al. 2005, Brust and Waniek 2010) and the Saharan desert is considered the largest source of particulate material in the world (Goudie and Middleton 2001). Its contribution is almost two thirds of the global dust production, and approximately $26 \%$ reaches the oceans (Jickells et al. 2005).

Atmospheric dust has an important impact on the ocean biogeochemistry as it fertilizes the ocean with rich iron minerals (Mahowald et al. 2009). Iron is the fourth most abundant element in the earth's crust, with an estimated abundance of $5.6310^{4} \mathrm{mg} \mathrm{kg}^{-1}$, while the concentration in the ocean is $210^{-3} \mathrm{mg} \mathrm{l}^{-1}$ (Lide 1996). Iron appears in the continental crust as primary (rockforming minerals) and/or supergenic (weathering) minerals, the most important of which are iron oxyhydroxides (magnetite $\mathrm{Fe}_{3} \mathrm{O}_{4}$, hematite $\mathrm{Fe}_{2} \mathrm{O}_{3}$, goethite $\mathrm{FeO}(\mathrm{OH})$, ilmenite $\mathrm{FeTiO}_{3}$, etc.) and, to a lesser extent, iron carbonates, sulfides-sulfates, silicates and phosphates (Hurlbut and Sharp 1998). Precambrian volcanic rocks and banded-iron formation (BIF) deposits are abundant in the crystalline basement of the West African Craton, for instance, in the Tiris region of the Western Sahara or Quidiat Iyil in Mauritania (Rocci et al. 1991, Lehbib et al. 2009). These Precambrian outcrops can be an important source area of iron oxyhydroxides and iron supergenic minerals associated with weathering processes (such as iron phyllosilicates, carbonates and sulfates), which have been reported as Saharan dust particles (Menéndez et al. 2007, Klaver et al. 2011). The aerosols from the continental crust are therefore a main natural source of iron minerals in the open ocean, which are commonly carried in the form of clay, other silicates, and even iron oxy-hydroxide (Journet et al. 2008). Iron is a limiting micronutrient in some marine regions (Mills et al. 2004), but limitation is not a direct consequence of its trace concentration in seawater.

Atmospheric samplers (Menéndez et al. 2009, Gelado-Caballero et al. 2012), remote sensing (Torres et al. 2002, Kaufman et al. 2002), ocean sediment cores (Henderiks et al. 2002) and even sediment traps (Neuer et al. 2004, Alonso-González et al. 2010a,b, Brust et al. 2011) have been used to study aerosols and to infer the amount of atmospheric dust input to the North Atlantic (Neuer et al. 2004, Brust et al. 2011). The morphometric study of sediment particles is also of importance

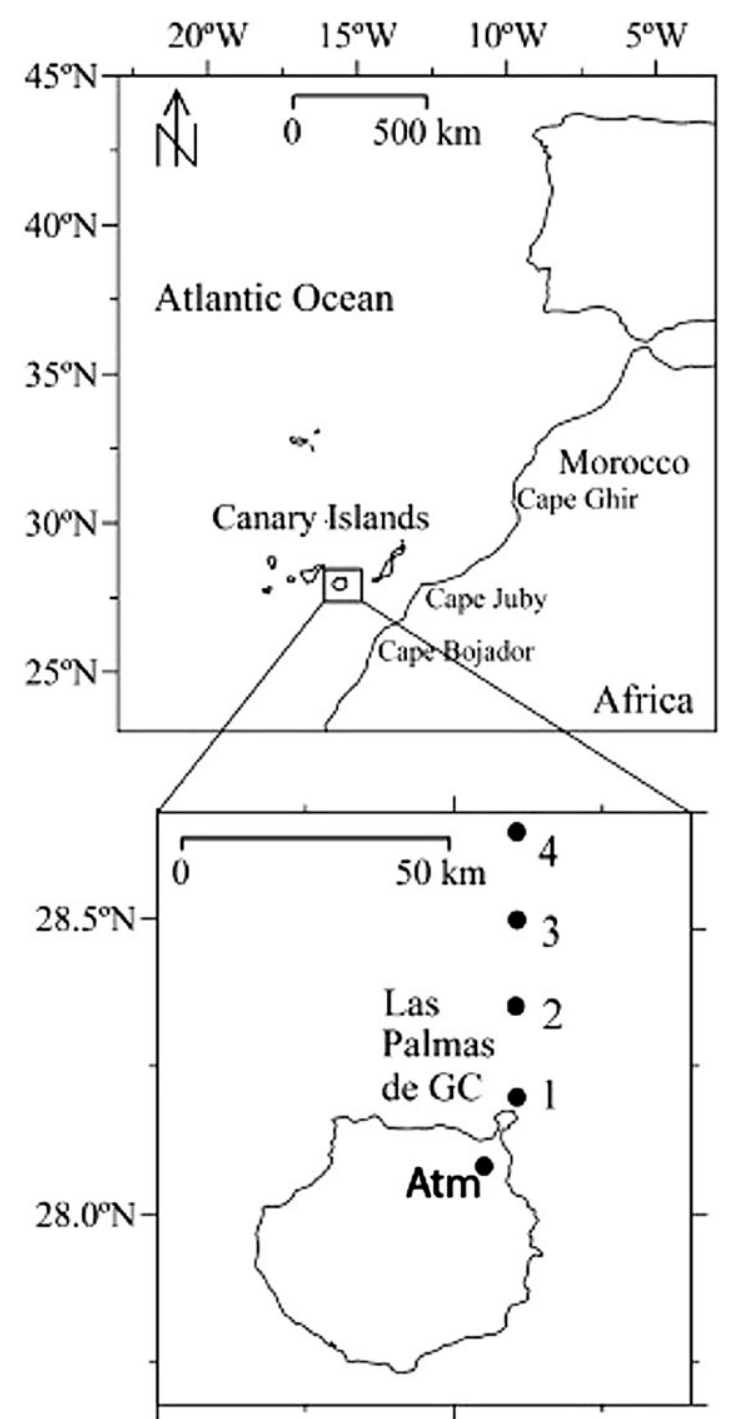

Fig. 1. - Location of the study area. Oceanographic stations (dots 1-4) and atmospheric station (Atm) at $300 \mathrm{~m}$ above sea level.

to understand their physical and chemical interactions with the environment. Irregular particles have a larger contact surface with the surrounding fluid, so they offer more resistance to sinking (Rawle 2003), and can reach longer distances in suspension (in both air and water). A larger surface ratio implies higher chemical reactivity, favouring cohesive properties and the tendency towards formation of marine aggregates and ballasts (Alonso-González et al. 2010b). The possible refilling effect of mineral particles in organic aggregates decreases their porosity and these mineral particles act as ballast, increasing their relative density and hence the sinking velocities hundreds of times (De la Rocha and Passow 2007).

The main goal of this study was to characterize and compare the grain size, grain morphology and mineral composition of Saharan dust inputs and to monitor their distribution in the mixed layer. Textural and mineralogical characterization in the ocean and air environments is important to understand the role of atmospheric particle inputs in the Canary Region and their effect on the biogeochemistry of surface waters. 


\section{MATERIALS AND METHODS}

\section{Collection and treatment of samples}

Weekly cruises were performed north of Gran Canaria Island (Canary Islands) from 20 January to 13 April 2011. Water samples were obtained at four stations $18.5 \mathrm{~km}$ apart (Fig. 1). Two dust events were studied: the first from 19 to $25 \mathrm{March}$, and the second from 31 March to 2 April (Fig. 2). The dust Events were identified by the dust load charts provided by the DREAM forecasting model. These concentration data charts for forecasting and real time analysis are available on the Barcelona Supercomputing Centre (2011) web site and its hourly back trajectories are available on the Spain HYSPLIT Programme web site (Fig. 3). Saharan plume dust was defined by the BSC-DREAM model with a threshold concentration higher than 10 $\mathrm{mg} \mathrm{m}^{-3}$ (excluding the local background dust concentrations of the plume dust path). The atmospheric concentration measurements were obtained from the Las Rehoyas observing station (Red de Control y Vigilancia de la Calidad del Aire, Gobierno de Canarias 2011).

During the first dust event, samples were taken at $10 \mathrm{~m}$ depth using a Niskin bottle; during the second event, samples were collected at $150 \mathrm{~m}$ depth using a sediment trap with an area of $0.125 \mathrm{~m}^{2}$ (Table 1).

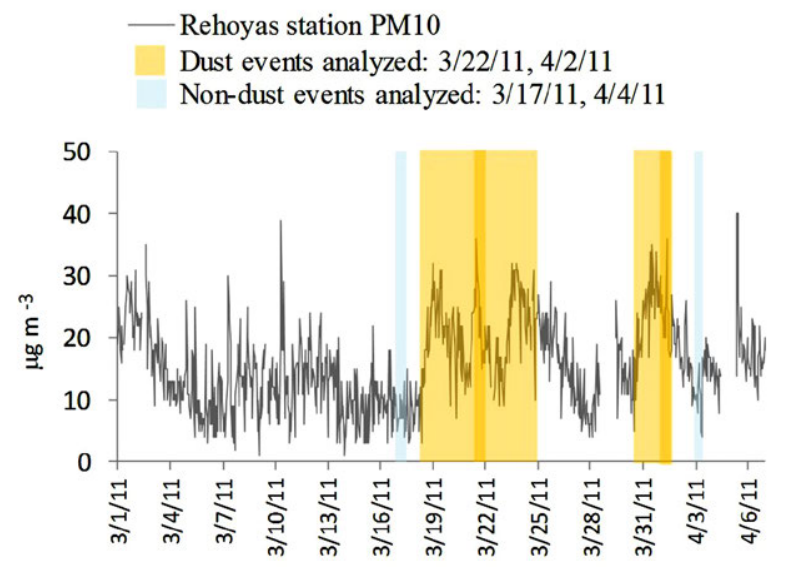

Fig. 2. - Airborne concentration in particles $<10$ mm (PM10) measured at Las Rehoyas station, Gran Canaria Island. Selected periods during both dust and non-dust events are highlighted. Las Rehoyas is an urban station placed at 86 m.a.s.l in the northeast of Las Palmas de Gran Canaria (source: Formulario de Datos Históricos de la Red de Control y Vigilancia de la Calidad del Aire, Gobierno de Canarias; http://www.gobiernodecanarias.org/medioambiente/ calidaddelaire/datosHistoricosForm.do).

Samples collected on the days previous to each Saharan dust event were considered as the control sample. During Saharan dust events and on non-Saharan dust days, atmospheric samples were obtained in order to compare with the ocean water samples.

\section{Backtrajectory at $100 \mathrm{~m}$}

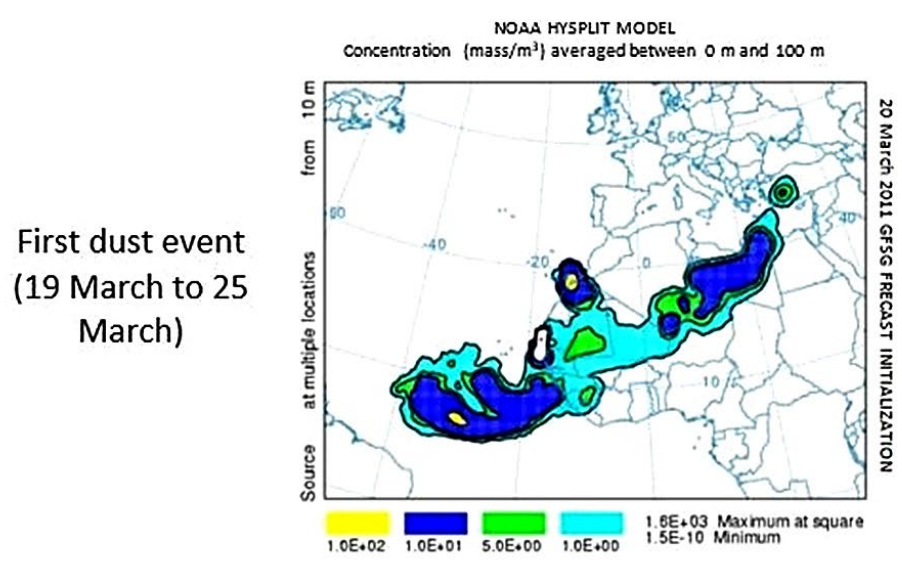

NOAA HYSPLT MODEL concentration $\left(\mathrm{mass} / \mathrm{m}^{3}\right.$ ) averaged between $0 \mathrm{~m}$ and $100 \mathrm{~m}$

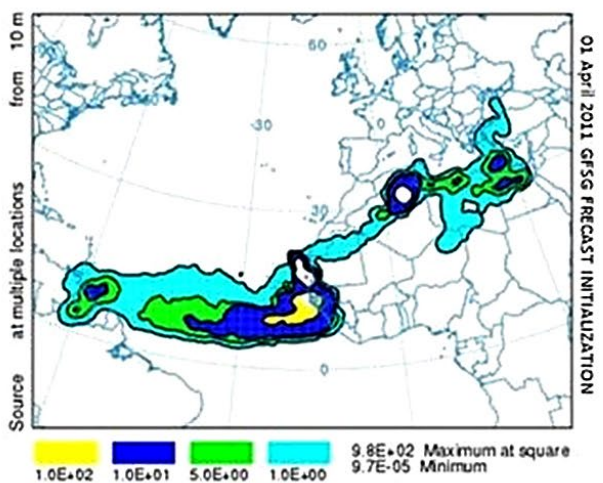

Backtrajectory at $5000 \mathrm{~m}$
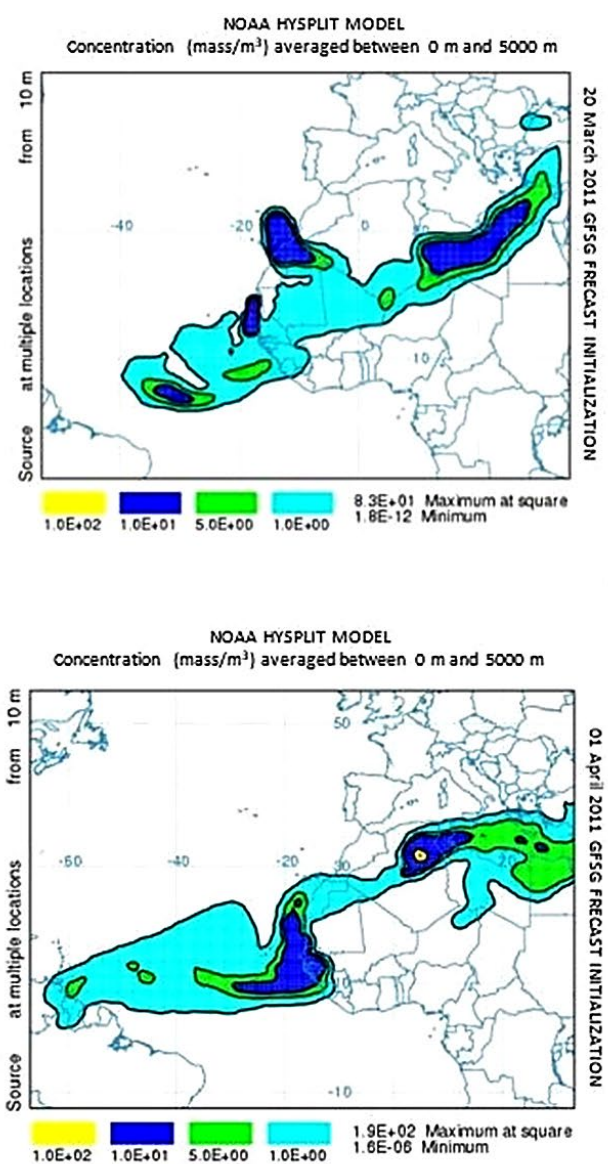

Fig. 3. - Back trajectory of dust events analysed: 19 March to 25 March and 31 March to 2 April. The origin of the dust event is localized to western Algeria, northern Mauritania and the Western Sahara, relatively close to the sample area (Canary Basin). 
Table 1. - Samples description.

\begin{tabular}{lllccc}
\hline Type & $\begin{array}{c}\text { Altitude or depth } \\
\text { of sampling }\end{array}$ & \multicolumn{1}{c}{ Method } & No $^{\text {of samples }}$ & \multicolumn{2}{c}{$\mathrm{N}^{\circ}$ of images analysed } \\
(grain size - morphometry) & (mass estimation- mineralogy) \\
\hline Airborne & 300 m.a.s.l. & Airmetrics@ Minivols & 4 & 36 & 26 \\
& 10 m depth & Niskin Bottle & 4 & 24 & 21 \\
Ocean water & 150 m depth & Technicap PPS 3/3-24 S & 4 & 24 & 23 \\
Total & & time-series sediment trap & 12 & 84 & 64 \\
\hline
\end{tabular}

The sediment trap was deployed in a system drift at $150 \mathrm{~m}$ depth between Stations 3 and 4 (Fig. 1) in order to collect the sinking particles. Those samples were collected over 252 hours using a Technicap PPS 3/3-24S time-series sediment trap with a sampling frequency of 12 hours, so it was possible to discriminate between day and night. The preserving solution for the bottles was filled with filtered seawater, plus $5 \mathrm{~g} \mathrm{~kg}^{-1} \mathrm{NaCl}$ solution, and made up to $3.5 \%$ buffered formalin. This sample manipulation and subsequent filtering were performed following Alonso-González et al. (2010a).

Airborne samples were collected at a station on land located on a building roof $300 \mathrm{~m}$ above sea level (Fig. 1) through Airmetrics ${ }^{\circledR}$ Minivol low volume samplers (5 L of air per minute). They worked continuously and samples were obtained weekly for particle fraction larger than $2.5 \mathrm{~mm}$ using $\mathrm{PM}_{10}$ and $\mathrm{PM}_{2.5}$ impactors. These fractions represent around $80 \%$ of the total particle matter on airborne dust (Menéndez et al. 2009). $\mathrm{PM}_{10}$ and $\mathrm{PM}_{2.5}$ stand for particulate matter that passes through a size-selective inlet with a $50 \%$ efficiency cut-off at 10 and $2.5 \mu \mathrm{m}$ aerodynamic diameter, respectively.

Ocean samples were previously filtered in the laboratory through a 200-um sieve to avoid zooplankton. This sieving did not affect dust particles collected since normal size ranges between 0.1 and $200 \mu \mathrm{m}$ (Menéndez et al. 2009). Afterwards, atmospheric and oceanic samples in watery suspension were filtered using $\mathrm{Nu}-$ cleopore $^{\odot}$ and glass fibre GF/C filters (pore diameters of 0.2 and $1.2 \mu \mathrm{m}$, respectively). The large zooplankton (swimmers) was manually removed following the procedure described by Alonso-González et al. (2010a).

After filtration, samples were treated with hydrogen peroxide $(3 \%)$ previously heated to $50^{\circ} \mathrm{C}$ for 30 minutes in order to eliminate organic matter. The procedure was repeated due to the low percentage of peroxide used. Finally, samples were dried at $50^{\circ} \mathrm{C}$ and preserved at $20^{\circ} \mathrm{C}$. Hydrogen peroxide can act as an oxidant of Fe (II) at nanomolar levels (González-Dávila et al. 2005). However, iron solubility is inversely related to the size of the particles for Saharan dust, which shows the lowest values of solubility (Baker and Jickells 2006). Crystalline Fe oxy-hydroxide phases (microparticles of goethite and/or hematite) and Fe-containing clay minerals are common in Saharan dust (Klaver et al. 2011), and they represent the "slow" solubility Fe pool of mineral Saharan dust. Experimentally, microparticles of crystalline Fe oxide phases and clays were completely dissolved at $\mathrm{pH}<3$ for hundreds of hours, while Fe nanoparticles $(<0.1 \mathrm{~mm})$ only last several minutes in the same pH conditions (Shi et al. 2011).

\section{Image treatment and morphometric analysis}

The filtered samples were photographed with a Leika ${ }^{\circledR}$ MZ6 stereomicroscope equipped with a photographic camera and non-polarized natural light at an image resolution of 5.0 megapixels, using a $12.6 \times$ and $40 \times$ zoom. Samples from the trap could only be photographed using a $12.6 \times$ zoom due to the low amount of particles observed at $40 \times$. The real dimensions in these pictures were determined using a calibrated grid. Airborne samples were also analysed using an electron microscope (SEM-EDX) to obtain images at $150 \times$ and $500 \times$, both of them at 0.8 megapixels resolution.

Each filter image passed through an image treatment. A set of 84 images were made (Table 1). Mineralogical information was also obtained from each filter with the electron microscope (JEOL 5410 equipped with an energy dispersion $\mathrm{X}$ ray analyser, EDS, OXFORD and ISIS-LINK model). This microscope was used at $20 \mathrm{KV}$ with a high vacuum, sounding current around $10^{-9} \mathrm{~A}$, and $20 \mathrm{~mm}$ work distance.

Each individual particle or agglomerate was transformed into irregular polygons through image treatment. In this process, the most suitable Red Green Blue threshold was fixed to binarize the images (conversion to black and white) to obtain the best possible discrimination. Similar light conditions were used for each picture to guarantee a standard process. Once binarized, the images were converted from raster format to a vector format through ArcGIS ${ }^{\circledR}$ software (Fig. 4), from which the geometrical properties (area, $\mathrm{A}_{\mathrm{p}}$ and perimeter, $\mathrm{P}$ ) of each polygon were obtained.

The zoom used in the image analysis could change the perception of the size in the analysed particle, and this is a factor that has to be considered when images analysis is used in granulometry measures (see Table 2). In this case, it was decided to use the zoom in which most amounts of particles were identified (40x for ocean surface particles, $12.5 \times$ for sediment trap particles).

Grain size analysis of particles was performed according to Blott and Pye (2008). In this study, the percentage volume was used to evaluate the grain-size distribution. The statistic parameters were obtained using Gradistat $4.0^{\circledR}$ software (Blott and Pye 2001).

The parameters used to describe the grain size distribution were (a) average size, (b) sorting, (c) symmetry or preferential spread (skewness) to one side of the average, and (d) degree of concentration of the grains relative to the average (kurtosis), following the descriptions of Blott and Pye (2001). For each particle, the number of pixels that it covered in $2 \mathrm{D}$ was estimated. The particles formed by fewer than three pixels were considered as noise. The parameters used to de- 


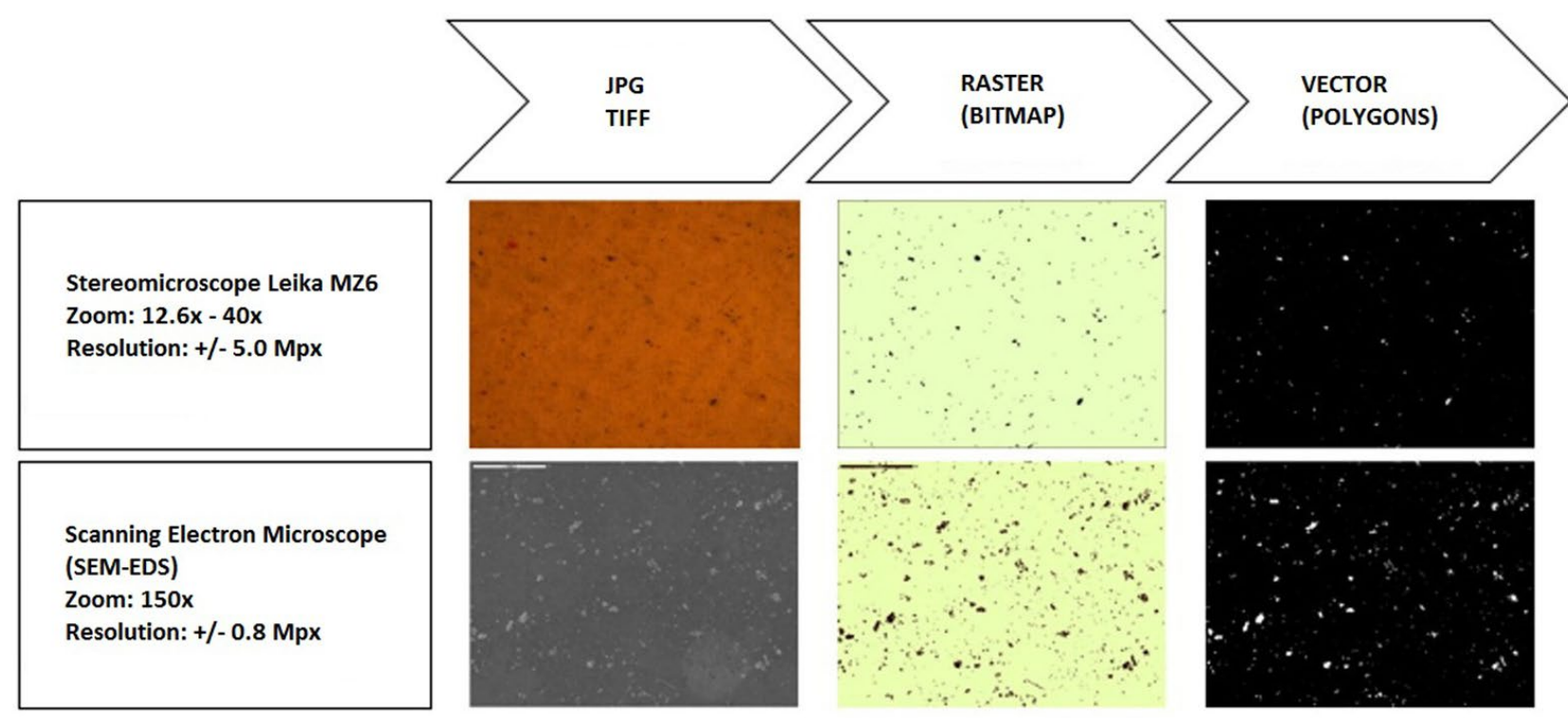

Fig. 4. - Image treatment process. The morphometric characteristics area, perimeter, length of major and minor axis, and number of pixels were measured in the vectorized images.

Table 2. - Grain-size parameters of samples determined by optical and electronic microscopy. * non-dust event; ** dust event.

\begin{tabular}{|c|c|c|c|c|c|c|}
\hline Sample & Zoom & Particles analysed & Mean size $(\mu \mathrm{m})$ & Sorting & Skewness & Kurtosis \\
\hline Airborne $*$ & $500 \times$ & 882 & 4 & 2.0 & 0.1 & 1.0 \\
\hline \multirow[t]{3}{*}{ Airborne ** } & $12.6 \times$ & 8531 & 51 & 2.2 & -0.2 & 0.8 \\
\hline & $40 \times$ & 17736 & 37 & 2.2 & 0.0 & 0.8 \\
\hline & $150 \times$ & 15120 & 21 & 2.3 & -0.1 & 1.0 \\
\hline \multirow[t]{2}{*}{$10 \mathrm{~m} \mathrm{depth}^{*}$} & $12.6 x$ & 2805 & 43 & 2.0 & -0.1 & 1.0 \\
\hline & $40 \times$ & 1198 & 30 & 1.7 & -0.3 & 0.9 \\
\hline \multirow[t]{2}{*}{$10 \mathrm{~m} \mathrm{depth}^{* *}$} & $12.6 x$ & 7156 & 70 & 2.0 & -0.2 & 0.9 \\
\hline & $40 \times$ & 4140 & 33 & 1.7 & -0.4 & 1.0 \\
\hline $150 \mathrm{~m}$ depth day* & $12.6 x$ & 966 & 24 & 1.7 & 0.0 & 1.2 \\
\hline $150 \mathrm{~m}$ depth night* & $12.6 x$ & 159 & 32 & 1.7 & -0.4 & 1.0 \\
\hline $150 \mathrm{~m}$ depth day** & $12.6 x$ & 158 & 55 & 1.8 & -0.1 & 0.9 \\
\hline $150 \mathrm{~m}$ depth night $* *$ & $12.6 x$ & 724 & 35 & 1.6 & -0.4 & 1.0 \\
\hline
\end{tabular}

scribe the particle characteristics were irregularity and sphericity or circularity (aspect ratio [AR], Blott and Pye 2008). The irregularity (IC) is defined as

$$
I C=\sqrt{\frac{4 \pi A}{p^{2}}}
$$

where $A$ is a circle with the same particle area as the actual perimeter of the grain, and $p$ is the perimeter (Blott and Pye 2008). The particle circularity was described through the AR (Zingg 1935) corresponding to:

$$
A R=\frac{L_{\min }}{L_{\max }}
$$

where $L_{\min }$ is the minor axis and $L_{\max }$ the major axe of the circumscribing ellipse.

Since this work was based on a 2D image treatment, it was not possible to analyse other aspects such as the shape and roundness.

\section{Mineralogy and mass estimations}

Through the basic morphometric parameters of particles it was possible to project their bidimensional image to a volume. Considering that the volume of the ellipsoid is between those of the sphere and spheroid, the ellipsoid geometry was used for the volume calculation, following the procedures of Okada et al. (2001).
The particle volume was calculated in the whole filter $\left(V_{\text {filter }}\right)$ by measuring all the particles of the photograph $\left(V_{\text {photo }}\right)$. The photographed area is in square pixels multiplied by its respective scale. The number of pictures in each sample $\left(A_{\text {photo }}\right)$, and the effective filter area, which corresponds to a circumference of $43 \mathrm{~mm}$ diameter $\left(A_{\text {filter }}\right)$ multiplied by a unit conversion factor:

$$
V_{\text {filter }}=V_{\text {photo }} \frac{A_{\text {filter }}}{A_{\text {photo }}}
$$

Using SEM-EDS it was possible to determine the main chemical composition of the analysed particles, which was used to infer their mineralogy and therefore to estimate the mean density of each sample. Interference of $\mathrm{Si}$ and $\mathrm{Zn}$ composition was found in SEM-EDX analyses as a result of the glass fibre filter composition. However, this interference was continuous and homogeneous in all filters and could be excluded. The mineralogical characterization was made with particles randomly selected in each image, with a larger zoom $(500 \times)$ because it was necessary for the geochemical identification. This allowed the researchers in this study to determine the percentage $\left(C_{i}\right)$ of each mineral type. In addition, through the density of the different minerals $\left(\rho_{i}\right)$, it was also possible to obtain the average weight density of the whole sample through the expression: 

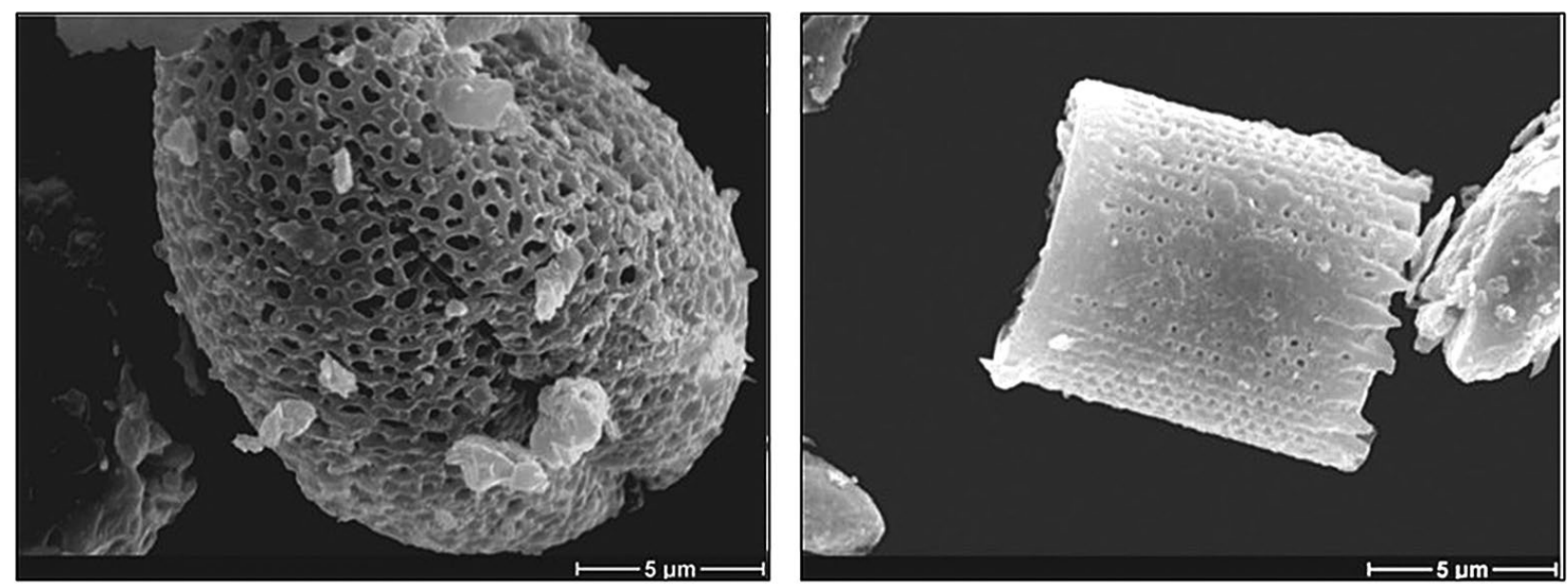

Fig. 5. - Diatoms typical of those deflated from desiccated Saharan-Sahelian lakes, e.g. Aulacoseira granulata, deposited on Gran Canaria in dense calima conditions on 4 March 2004 (images courtesy of Dr. Edward Derbyshire).

$$
\bar{\rho}=\sum C_{i} \rho_{i}
$$

Once the density and volume of all the particles present in the filter was known, the total mass $\left(M_{\text {filter }}\right)$ was calculated as

$$
M_{\text {filter }}=\bar{\rho}_{\text {sample }} \times V_{\text {filter }}
$$

This mass estimation corresponded to the inorganic fraction of samples, and therefore both the concentration and flux values were related to this fraction.

Scanning electron microscopy (SEM) is a nondestructive technique that permits the direct observation of the morphometry and the geochemical characterization of dust particles. This technique has been widely used in desert dust analysis (grain size distribution, morphometry and mineralogy; Shi et al. 2012). In the present study, SEM was used for quantification of particle volume and mass analysis, because this technique has been successfully used for morphometric analysis of volcanic ashes (Ersoy 2010).

It was considered that this direct particle mineralogy procedure is more accurate than the conventional chemical digestion (Neuer et al. 2004) to determine the lithogenic fraction. The conventional analysis, determines the litogenic fraction by the difference between total mass and the biogenic components removed by the digestion (i.e. opal, carbonates and organic matter), in which lithogenic material (i.e. continental carbonates and opal from lake diatoms, see Fig. 5) was also removed. This conventional technique may underestimate the lithogenic fraction, particularly in the dust from the Sahara, where it is common to found carbonates (calcite, aragonite and dolomite) (Menéndez et al. 2007, Scheuvens et al. 2013) and some quantities of amorphous silica such as opaline diatoms that may be destroyed by chemical digestion.

The concentration of particulate matter in the three environments (air, $10 \mathrm{~m}$ and $150 \mathrm{~m}$ depth) was also determined. These concentrations were directly obtained from the volume of filtered air and water at 10 $\mathrm{m}$ depth. The samples obtained from the trap $(150 \mathrm{~m}$ depth) were flux data $\left(\mathrm{mg} \mathrm{m}^{-2} \mathrm{~d}^{-1}\right)$, since the mass values are related to the area of the trap $\left(0.125 \mathrm{~m}^{2}\right)$ and to the elapsed time to collect each sample $(12 \mathrm{~h})$. These flux data were transformed into concentration after being multiplied by the settling velocity $\left(83.6 \mathrm{~m} \mathrm{day}^{-1}\right.$ for non-dust and $208.3 \mathrm{~m} \mathrm{day}^{-1}$ for the dust event), which was obtained from the Stokes law, with the assumption of a static system (Table 3 ). This assumption is quite reasonable considering the drift motion of the sediment trap. Similarly, the dust concentration was converted to atmospheric dust flux (Table 3) assuming a settling rate of $1.4 \mathrm{~cm} \mathrm{~s}^{-1}$ (Neuer et al. 2004). The $10 \mathrm{~m}$ depth concentration data was not transformed into a flux because of the large amount of turbulence at this depth, which would make the settling velocity uncertain.

\section{RESULTS}

\section{Grain size}

The most frequent particle size in the samples was coarse silt (37 mm; Table 2). However, the grain size distribution showed high dispersion (high sorting value), and a slight displacement to finer sizes than the mode (negative skewness, Table 2). The particle size was 4 to $51 \mu \mathrm{m}$ in the atmospheric samples, 30 to 70

Table 3. - Mean density, lithogenic flux and concentration of particles in airborne and seawater samples. * calculated assuming a settling rate of $1.4 \mathrm{~cm} \mathrm{~s}^{-1}$ (Neuer et al. 2004); ** not calculated because the high turbulence at $10 \mathrm{~m}$ depth makes the settling velocity uncertain; *** calculated by mean flux vs. settling velocity. Settling velocity $\left(83.6 \mathrm{~m}\right.$ day $^{-1}$ for non-dust and $208.3 \mathrm{~m} \mathrm{day}^{-1}$ for dust event) obtained by the Stokes law, assuming a static system due to the drift motion of the sediment trap.

\begin{tabular}{lccc}
\hline Mineral particulate matter & $\begin{array}{c}\text { Density } \\
\left(\mathrm{kg} \mathrm{m}^{-3}\right)\end{array}$ & $\begin{array}{c}\text { Flux } \\
\left(\mathrm{mg} \mathrm{m}^{-2} \mathrm{~d}^{-1}\right)\end{array}$ & $\begin{array}{c}\text { Concentration } \\
\left(\mathrm{mg} \mathrm{m}^{-3}\right)\end{array}$ \\
\hline Airborne non-dust event & 2727 & $5.685^{*}$ & 0.005 \\
Airborne dust event & 2968 & $122.170^{*}$ & 0.101 \\
10 m depth non-dust event & 3368 & $---* *$ & 3.493 \\
10 m depth dust event & 3576 & $---* *$ & 26.506 \\
150 m depth non-dust event & 3469 & 0.15 & $0.0018 * * *$ \\
150 m depth dust event & 3384 & 0.24 & $0.0012 * * *$ \\
\hline
\end{tabular}


Table 4. - Selection of particle images information: number of pixels, elongation (AR) and irregularity (IC) indexes. High elongation and irregularity of the particles correspond to lower index values. Note that the high particle size (in pixels, F and L) interferes with a good interpretation of both morphometric indices (AR and IC).

\begin{tabular}{|c|c|c|c|c|c|}
\hline Particle & Size in pixels & Elongation (AR) & Particle & Size in pixels & Irregularity (IC) \\
\hline A & 3 & 0.95 & $\mathrm{H}$ & 22 & 0.83 \\
\hline B & 333 & 0.80 & I & 580 & 0.70 \\
\hline $\mathrm{C}$ & 101 & 0.50 & $\mathrm{~J}$ & 703 & 0.50 \\
\hline D & 39 & 0.25 & K & 761 & 0.30 \\
\hline $\mathrm{E}$ & 1003 & 0.12 & $\mathrm{~L}$ & 1455 & 0.13 \\
\hline $\mathrm{F}$ & 1455 & 0.07 & & & \\
\hline
\end{tabular}

Table 5. - Morphometry of each type of sample during dust and non-dust events. Mean values and standard deviation (between brackets) of the elongation (AR) and irregularity (IC) index.

\begin{tabular}{|c|c|c|c|c|c|c|}
\hline & \multicolumn{2}{|c|}{$\%$ Particles } & \multicolumn{2}{|c|}{$\mathrm{IC}$} & \multicolumn{2}{|c|}{ AR } \\
\hline & Non-dust event & Dust event & Non-dust event & Dust event & Non-dust event & Dust event \\
\hline \multicolumn{7}{|l|}{ Airborne: } \\
\hline $1-2 \mu \mathrm{m}$ & $1 \%$ & $1 \%$ & $0.90(0.00)$ & $0.72(0.06)$ & $0.79(0.17)$ & $0.62(0.24)$ \\
\hline $2-4 \mu \mathrm{m}$ & $84 \%$ & $53 \%$ & $0.80(0.10)$ & $0.64(0.09)$ & $0.6(0.1)$ & $0.60(0.19)$ \\
\hline $4-8 \mu \mathrm{m}$ & $14 \%$ & $16 \%$ & $0.70(0.10)$ & $0.65(0.09)$ & $0.68(0.05)$ & $0.65(0.16)$ \\
\hline $8-15.5 \mu \mathrm{m}$ & $1 \%$ & $17 \%$ & $0.60(0.10)$ & $0.64(0.08)$ & $0.43(0.17)$ & $0.61(0.15)$ \\
\hline $15.5-31 \mu \mathrm{m}$ & $0 \%$ & $11 \%$ & - & $0.57(0.10)$ & - & $0.57(0.17)$ \\
\hline $31-62.5 \mu \mathrm{m}$ & $0 \%$ & $2 \%$ & - & $0.55(0.09)$ & - & $0.65(0.09)$ \\
\hline \multicolumn{7}{|c|}{ Ocean: $10 \mathrm{~m}$ depth } \\
\hline $0.5-1 \mu \mathrm{m}$ & $31 \%$ & $31 \%$ & - & - & - & - \\
\hline $1-2 \mu \mathrm{m}$ & $11 \%$ & $11 \%$ & $0.73(0.05)$ & $0.73(0.05)$ & $0.61(0.24)$ & $0.65(0.25)$ \\
\hline $2-4 \mu \mathrm{m}$ & $34 \%$ & $31 \%$ & $0.58(0.08)$ & $0.58(0.08)$ & $0.54(0.15)$ & $0.54(0.17)$ \\
\hline $4-8 \mu \mathrm{m}$ & $9 \%$ & $10 \%$ & $0.56(0.11)$ & $0.56(0.11)$ & $0.61(0.16)$ & $0.60(0.15)$ \\
\hline $8-15.5 \mu \mathrm{m}$ & $8 \%$ & $8 \%$ & $0.55(0.12)$ & $0.53(0.13)$ & $0.66(0.14)$ & $0.63(0.15)$ \\
\hline $15.5-31 \mu \mathrm{m}$ & $5 \%$ & $6 \%$ & $0.54(0.06)$ & $0.49(0.13)$ & $0.59(0.15)$ & $0.61(0.17)$ \\
\hline $31-62.5 \mu \mathrm{m}$ & $1 \%$ & $2 \%$ & $0.42(0.11)$ & $0.50(0.13)$ & $0.57(0.28)$ & $0.60(0.18)$ \\
\hline \multicolumn{7}{|c|}{ Ocean: $150 \mathrm{~m}$ depth } \\
\hline $1-2 \mu \mathrm{m}$ & $0 \%$ & $0 \%$ & - & - & - & - \\
\hline $2-4 \mu \mathrm{m}$ & $68 \%$ & $74 \%$ & - & - & - & - \\
\hline $4-8 \mu \mathrm{m}$ & $12 \%$ & $10 \%$ & $0.71(0.07)$ & $0.71(0.08)$ & $0.61(0.23)$ & $0.59(0.25)$ \\
\hline $8-15.5 \mu \mathrm{m}$ & $12 \%$ & $8 \%$ & $0.66(0.09)$ & $0.62(0.12)$ & $0.64(0.17)$ & $0.61(0.15)$ \\
\hline $15.5-31 \mu \mathrm{m}$ & $8 \%$ & $5 \%$ & $0.63(0.08)$ & $0.56(0.13)$ & $0.61(0.15)$ & $0.59(0.15)$ \\
\hline $31-62.5 \mu \mathrm{m}$ & $1 \%$ & $3 \%$ & $0.55(0.20)$ & $0.56(0.13)$ & $0.56(0.23)$ & $0.61(0.17)$ \\
\hline
\end{tabular}

$\mu \mathrm{m}$ at $10 \mathrm{~m}$ depth, and 24 to $55 \mu \mathrm{m}$ at $150 \mathrm{~m}$ depth. The second aspect to be noted was the average grain size, which always increased during Saharan dust periods, as observed at both 10 and $150 \mathrm{~m}$ depth (Table. 2).

\section{Morphometry}

Morphological particle analysis showed a systematic error due to the square shape of pixels. The largest problem occurred in very small $(<10$ pixels) and very large particles (>1400 pixels, Table 4$)$. The complexity of particles in seawater was higher than in the atmosphere (see IC index in Table 5). Both environments suggest the same tendency in irregularity, with an increase with grain size. Particles were moderately elongated, but with high standard deviations. The AR showed no pattern of change relative to the particle size (from 2 to $150 \mathrm{~mm}$ ). Similar results were found in samples with the IC and the AR morphometric parameters, 0.06 being the maximum difference of irregularity in the same size range. It was not possible to differentiate between dust and non-dust events using morphometric indexes in any type of samples, due to their high standard deviation values (Table 5). 

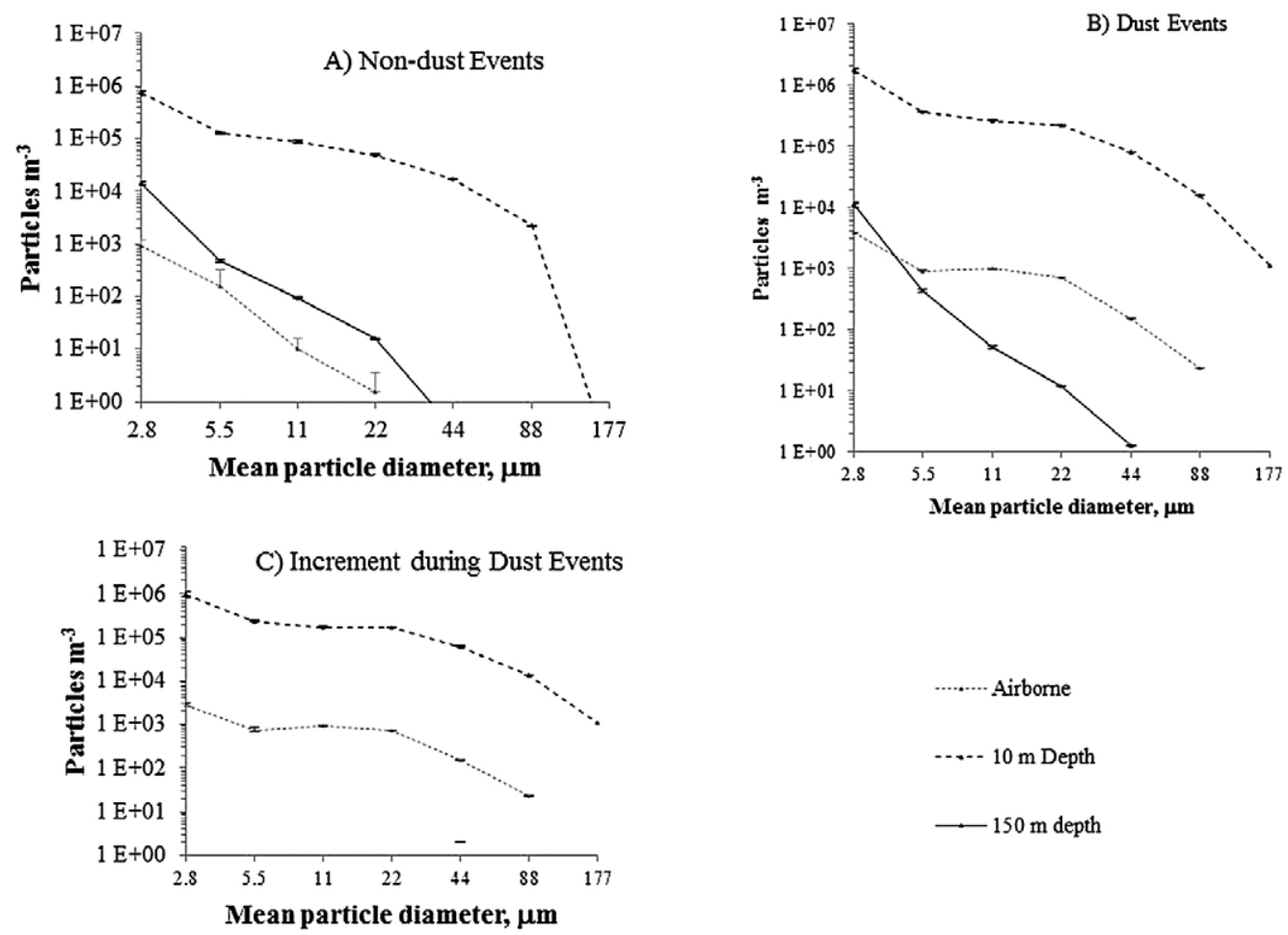

Fig. 6. - Number of particles per cubic metre (particles $\mathrm{m}^{-3}$ ) vs. particle size during non-dust (A), and dust events (B) from airborne and seawater samples (at 10 and $150 \mathrm{~m}$ depth). (C) Figure shows the increase in number of particles during dust events vs. grain size. Error bars are the standard deviation. Note that the number of particles increases for all particle sizes in atmospheric samples and at $10 \mathrm{~m}$ depth during dust events in all types of samples, while at $150 \mathrm{~m}$ depth the main difference is the increase in particle diameter.
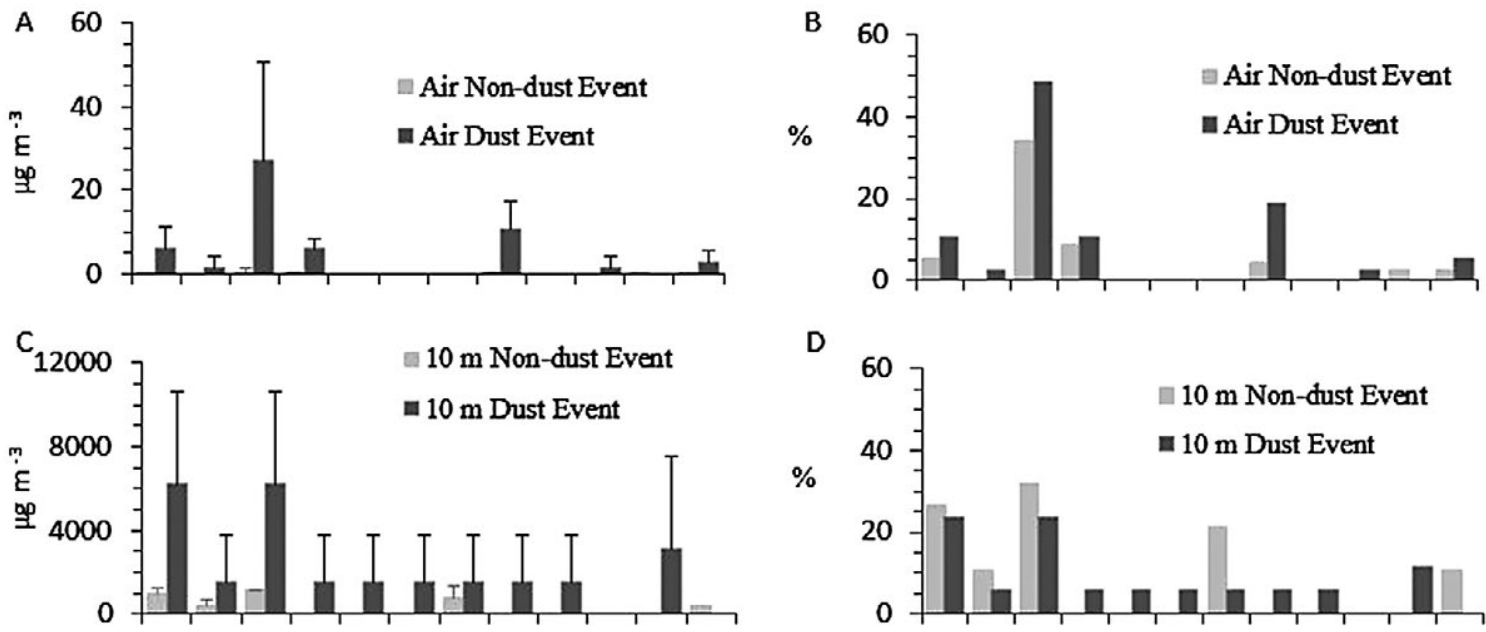

D
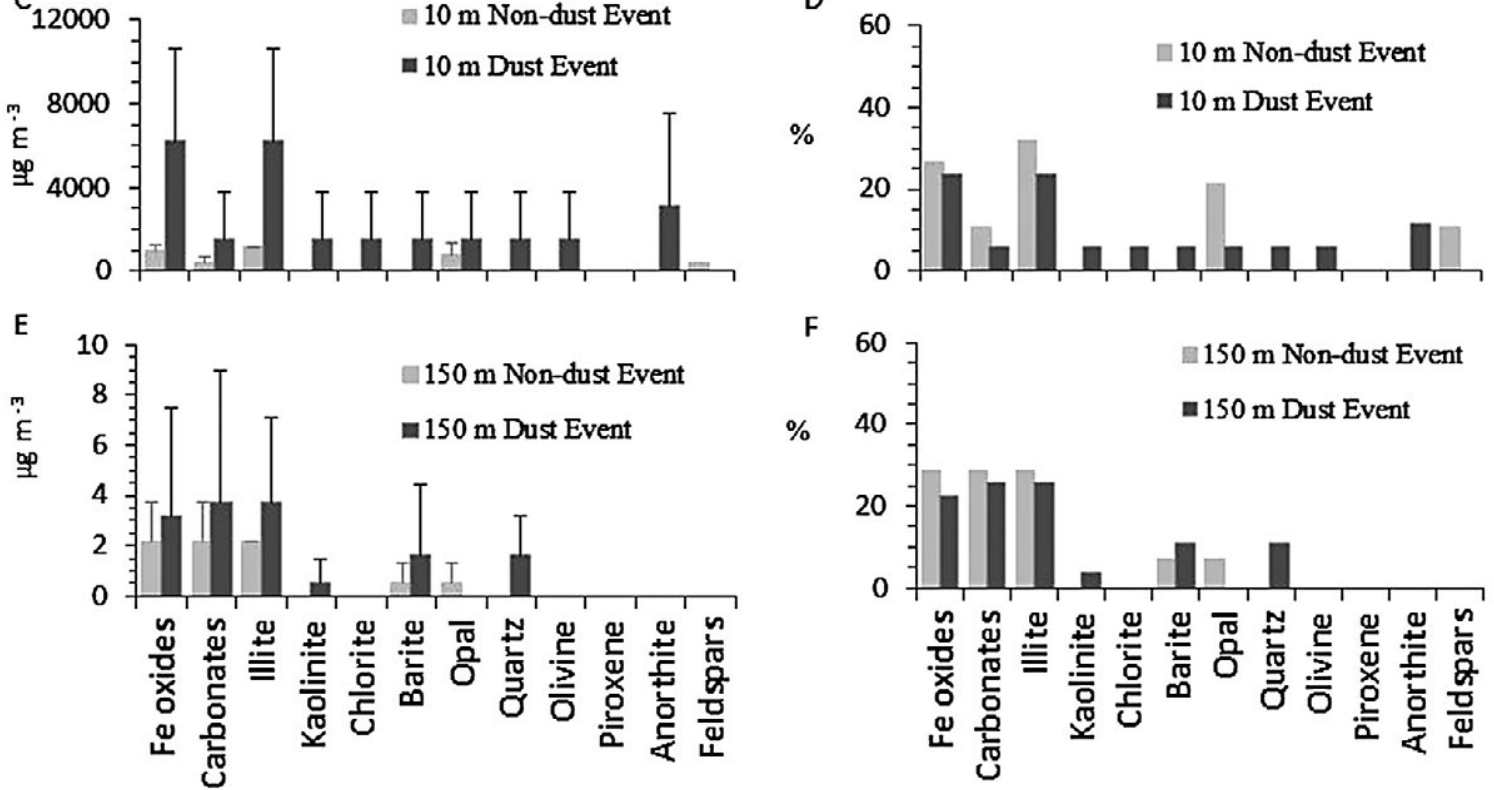

Fig. 7. - Mineral concentration $\left(\mathrm{mg} \mathrm{m}^{-3}\right)$ and percentage (\%) in airborne samples (A, B), at $10 \mathrm{~m}$ depth $(\mathrm{C}, \mathrm{D})$, and at $150 \mathrm{~m} \mathrm{depth}(\mathrm{E}, \mathrm{F})$ during dust and non-dust events. Error bars are the standard error. 


\section{Mass estimation}

The concentration measured with the stereomicroscope (12.6 and 40x) and the SEM (150x) were similar. The atmospheric samples showed lower concentration values than the oceanic samples (10 $\mathrm{m}$ depth), possibly due to the viscosity differences between the two fluids. As expected, during dust events both the concentration and flux increased significantly, the concentration by a factor of 20 in the airborne samples and 8 in the mixed layer, and flux by a factor of 1.6 at $150 \mathrm{~m}$ water depth (Table 3).

In both dust and non-dust conditions, the particle concentration at $10 \mathrm{~m}$ depth was two to four orders of magnitude higher than the concentration found in air and at $150 \mathrm{~m}$ depth (Fig. 6, Table 3). The most noteworthy difference between dust and non-dust events was found in atmospheric samples, where concentration increased in the dust events by two orders of magnitude. By contrast, a small decrease of particle concentration was found during dust events at $150 \mathrm{~m}$ depth (Fig. 6C).

\section{Mineralogy}

As expected, a large quantity of biogenic material was observed in the sediment trap samples. This feature was mainly related to the presence of foraminifers, radiolarians, faecal pellets and other organic aggregates with adhered mineral particles. The minerals found were mainly silicates (the tectosilicates quartz and opal, and the phyllosilicate illite), calcium-magnesium carbonates (calcite, aragonite and magnesium calcite), and iron oxy-hydroxides (hematite and goethite). Other silicates (the phyllosilicates chlorite and kaolinite; the tectosilicates plagioclase and alkali feldspar; the inosilicates pyroxene and the nesosilicate olivine), sulfates (barite and gypsum) and iron and titanium oxide (ilmenite) appeared in proportions lower than $15 \%$ (Fig. 7). Iron was found as a major chemical element in hematite, goethite and ilmenite, and in small amounts in illite, chlorite, pyroxene and olivine.

Illites, calcium-magnesium carbonates and iron oxy-hydroxides were found in all types of samples. Quartz appeared during dust events while opal was detected mainly in samples collected under non-dust conditions. The proportion of illite and quartz was higher in airborne than in marine samples, while iron oxy-hydroxides and carbonates showed the opposite pattern. In fact, the calcium-magnesium carbonate percentage at $150 \mathrm{~m}$ depth was more than twice that in the other environments.

\section{DISCUSSION}

\section{Grain size}

Saharan dust events sampled within hundreds of kilometres from the source indicate a mean diameter of airborne particle of between 72 and $74 \mu \mathrm{m}$ (Goudie and Middleton 2001), while numerous studies of dust transport over thousands of kilometres from the source have measured mean sizes of between 1 and $30 \mu \mathrm{m}$ (Goudie and Middleton 2001). The dispersed-phase particles have a diameter of approximately $0.001-1 \mathrm{~mm}$ (Levine 2001). Thus, the fine fraction of aeolian dust acts as a colloid. Recent evidence suggests that only a minor fraction of "dissolved" iron (i.e. the size fraction $<0.4$ $\mathrm{mm})$ is truly soluble $(<0.02 \mathrm{~mm})$ and we therefore lost this fraction in the filtration process (Parekh et al. 2008).

According to the model output from the Barcelona Supercomputing Centre and the Sahara Airmass Outbreak Model (application of HySPLIT) in 2011, the sources of the analysed dust events were the western Algeria, the Western Sahara and northern Mauritania (Figs 3 and 8). The size range shown in Table 2 varied between 4 and $51 \mu \mathrm{m}$ in the airborne samples, 30 and $70 \mu \mathrm{m}$ at $10 \mathrm{~m}$ depth, and 24 and $55 \mu \mathrm{m}$ at 150 $\mathrm{m}$ depth. These average particle diameters were in the same range as earlier data obtained from areas located around $1000 \mathrm{~km}$ from the dust source (Goudie and Middleton 2001).

\section{Morphometry}

The parameters used (IC and AC) were a fairly good indicator of the morphological characteristics. However, large errors were found in very small $(<10$ px) and very large particles (>1000 px). In the case of the smallest particles, the error was due to the high ratio between pixel and particle size, which increased the uncertainty of the index (see Table 4, particle A). The large particles have a large number of smaller irregularities, which produce a significant increase in their perimeters. Therefore, IC indicated high irregularity in quite regular particles (particles $\mathrm{E}$ and $\mathrm{F}$ in Table. 4). Another effect associated with large particles was the underestimation of the minor axis of the ellipse (b) and the elongation; in fact, they did not correspond to the real values (particle L, Table 4).

An additional issue was the relation between particle shape and mineralogy, since the structure of particles determines their falling velocity. For example, due to their laminated structure and sheet shape (Fig. 9B, F), illites have a higher resistance to deposition, remaining longer in the fluid than spherical or ellipsoidal particles. Laminar particles may even develop a vortex trail in their wake and start "wobbling" instead of settling along a straight line (Goossens 2005).

The simultaneously increase in irregularity and particle size in the water column samples could reflect the formation of aggregates (Wilson et al. 2008). This increase in particle complexity in relation to size has also been described in other morphological studies of airborne dust (Okada et al. 2001, Reid et al. 2003). The abundance of aggregates in larger sizes has been observed and, hence, a substantial increase in the perimeter/area ratio (Reid et al. 2003). However, similar values of morphological index were detected before and during a dust event at 10 and $150 \mathrm{~m}$ depth.

\section{Mass estimation}

Table 3 shows the bulk density of the particles in seawater, which was about $600 \mathrm{~kg} \mathrm{~m}^{-3}$ higher than that 
BSC-DREAM8b Lowest Model Level Dust Conc. $\left(\mu \mathrm{g} \mathrm{m}^{-3}\right)$
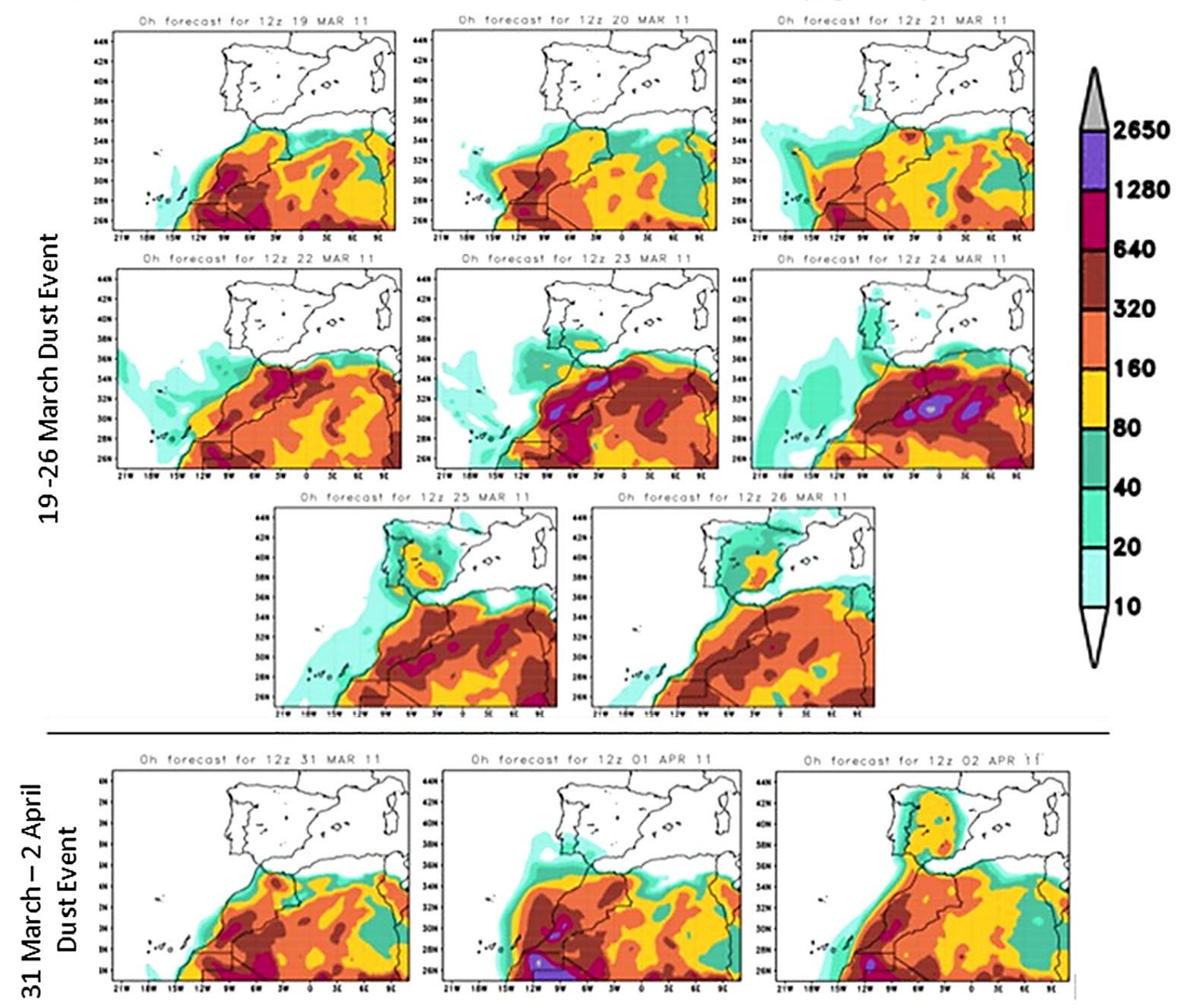

Fig. 8. - Dust events of 19 to 26 March and 31 March to 2 April derived from the DREAM model of the Barcelona Supercomputing Centre (http://www.bsc.es/earth-sciences/mineral-dust-forecast-system). The circle mark indicates Gran Canaria Island, where the samples were taken, and the intense colour (higher concentration) corresponds to the possible source of the dust event (northern Mauritania and western Algeria).

of the atmospheric ones. This difference must be due to various factors, including the change in physical properties of the two fluids: the seawater density and viscosity at $20^{\circ} \mathrm{C}$ are $1027.75 \mathrm{~kg} \mathrm{~m}^{-3}$ and $1.0810^{-3} \mathrm{Ns}$ $\mathrm{m}^{-2}$, respectively, while the corresponding values in the air at the same temperature are $1.204 \mathrm{~kg} \mathrm{~m}^{-3}$ and $1.8110^{-5} \mathrm{Ns} \mathrm{m}^{-2}$. Assuming no advection processes, such differences determined that the settling velocity (by Stokes's Law) was two orders of magnitude higher in air than in seawater. Therefore, when particles settle into the water a stagnation effect is produced, and this fact could explain the large concentration of particles in the water compared with the air (Table 3 ). However, the higher proportion of iron oxy-hydroxide minerals (such as hematite and goethite) observed in seawater samples may contribute to increase the average density of these samples and consequently favour their sinking.

As stated in the introduction, the lithogenic particles may act as ballast of the organic particles, increasing their sinking velocities hundreds of times (De la Ro- cha and Passow 2007). However, without discarding this sinking acceleration due to the ballast effect of the lithogenic particles, the observed effect in the surface waters seems to be the opposite, i.e. the increase of lithogenic particles and particularly in denser oxy-hydroxide minerals.

Unfortunately, there is little previous information from other authors using trap samples in the upper 200 $\mathrm{m}$. The lithogenic flux values calculated in this work were lower than those reported in the Canarian region by deeper samplers. For example, Brust et al. (2011) calculated an average annual lithogenic particle flux of $9.5 \mathrm{mg} \mathrm{m}^{-2} \mathrm{~d}^{-1}$ at $2000 \mathrm{~m}$ depth at Kiel 276 station $\left(33^{\circ} \mathrm{N}, 22^{\circ} \mathrm{W}\right)$. Ratmeyer et al. (1999) deployed several traps in the Canary Basin area $\left(29^{\circ} \mathrm{N}, 15^{\circ} \mathrm{W}\right)$, measuring a lithogenic flux of 0.7 to $43.6 \mathrm{mg} \mathrm{m}^{-2} \mathrm{~d}^{-1}$ at $1000 \mathrm{~m}$ depth, and between 1.2 and $61.8 \mathrm{mg} \mathrm{m}^{-2} \mathrm{~d}^{-1}$ at $3000 \mathrm{~m}$ depth. This tendency of the flux to increase with depth explains the lower flux found in the shallower layer sampled in the present work $\left(0.2 \mathrm{mg} \mathrm{m}^{-2} \mathrm{~d}^{-1}\right.$ at 150 
HEMATITE

A
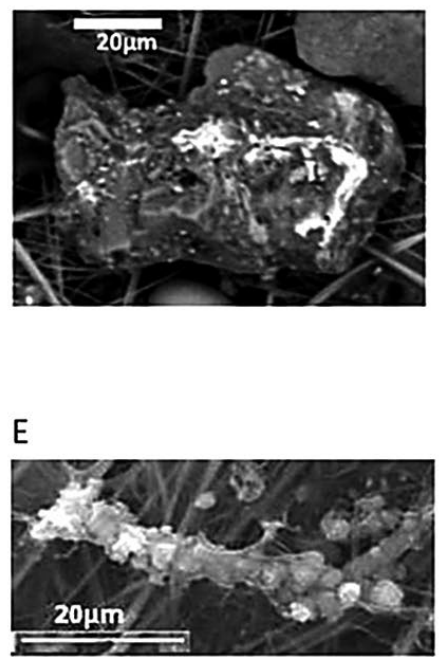

ILLITE

B

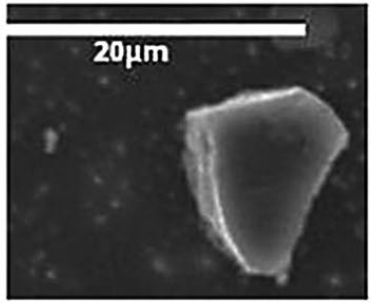

$\mathrm{F}$

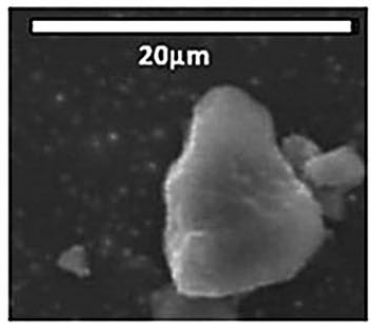

QUARTZ

C

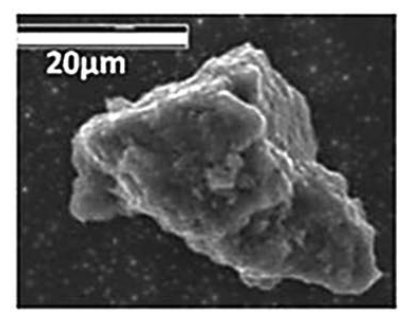

G

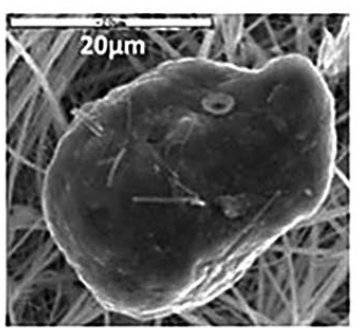

OPAL

D

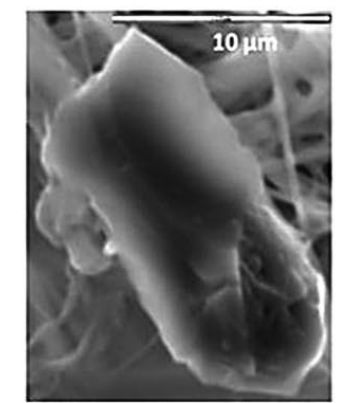

$\mathrm{H}$

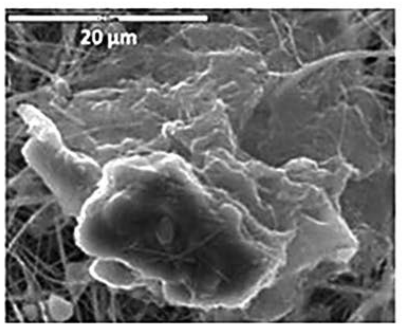

Fig. 9. - Electron microscope (SEM-EDX) images; A and B are incrusted iron oxide (white patches) in a transparent organic material; C and D are laminar structures of illite; $\mathrm{E}$ and $\mathrm{F}$ are granular structures of quartz; $\mathrm{G}$ is a biological structure composed of opal; $\mathrm{H}$ is a laminar structure composed of opal.

m depth). On the other hand, Fahl and Nöthig, (2007) measured annual fluxes in a shallow trap (150 m depth) in the Central Arctic, obtaining values of 3.9, 0.8 and $2.6 \mathrm{~g} \mathrm{~m}^{-2} \mathrm{y}^{-1}$ of lithogenic matter, $\mathrm{CaCO}_{3}$ and opal, respectively, and 11.3, 0.5 and $2.9 \mathrm{~g} \mathrm{~m}^{-2} \mathrm{y}^{-1}$, respectively, in a deeper trap (1550 $\mathrm{m}$ depth). These data also confirm the increase of lithogenic fluxes with depth, which could be explained by lateral sediment fluxes in deep water. In addition, lithogenic fluxes from the Arctic are one order of magnitude higher than those reported in this research for the Canary Basin at $150 \mathrm{~m}$ depth. This difference could be related to the presence of fluvial inputs in the Arctic, but is practically inexistent nowadays in the area of the Canary Islands.

\section{Mineralogy}

The dust events analysed in this study were generated close to northern Mauritania and the Western Sahara, which are around $700 \mathrm{~km}$ from the sampling area in Gran Canaria (Figs 3 and 8). From a geological point of view, this African area contains the West African Craton (the Reguibat Shield with Archean and Eburnean domains, of Precambrian age), the Mauritanides Fold Belt (Paleozoic age) and the Post-Paleozoic sedimentary cover (Taoudeni Basin to the east and Coastal Basin to the west), as described by Rocci et al (1991) and Soulaimani and Burkhard (2008), among other authors. The Precambrian materials are formed by granitic rocks, volcanic and volcanoclastic formations, ophiolites, quartzites, migmatitic gneiss and ferruginous quartzites (BIF, Bronne and Chauve 1979, Lehbib et al. 2009).

The Paleozoic metamorphic rocks of the Mauritanides Fold Belt contain limestone, dolomites, sand- stones, mudstones, shales and slates. In addition, these Precambrian and Paleozoic materials are covered and surrounded by varied Post-Paleozoic detrital sediments and soils. Therefore, many airborne minerals cited in this work may be derived mainly from the erosion of these Precambrian, Paleozoic and Post-Paleozoic rocks. Thus, quartz, plagioclase and K-feldspar mainly derive from granitic rocks, migmatitic gneiss, quartzites and shales; olivine, pyroxene, feldspar, ilmenite, hematite, goethite may derive from volcanic, ophiolitic, volcanoclastic and BIF series; Ca-Mg carbonates derive from limestones, dolomites and soils; and illite, kaolinite, opal, chlorite, gypsum and barite derive from soils and sediments produced by the weathering of old magmatic, metamorphic and sedimentary rocks. Consequently, there are many types of rocks in this part of Mauritania and the Western Sahara, producing varied detrital materials by erosion and these fine grains can be easily transported to the Atlantic Ocean and the Canary Island domains in dust events.

Most of the silicate lithogenic material (e.g. illite and quartz) was found on atmospheric samples compared to those at $150 \mathrm{~m}$ depth (Fig. 7); this finding could be explained by the southward direction of the Canary Current, as was shown in the ESTOC data analysis reported by Neuer et al. (2004). The opposite pattern was observed south of the Canaries, close to Mauritania $\left(\sim 20^{\circ} \mathrm{N}\right)$, where Bory et al. (2002) found that values at the deeper trap fluxes were 2-3 times larger than those of atmospheric dust, showing a retention effect of dust material in the water column being transported southward by the Canary Current.

The finding of quartz in the studied particles suggests that quartz is an excellent proxy for lithogenic material of exogenous origin of the Canary Islands 
due to its absence in the volcanic material. The $\mathrm{Ca}$ nary Archipelago is related to an oceanic intraplate hot spot and the volcanic materials which formed the islands varied the geochemical compositions between ultramafic-mafic (e.g. basanites, nephelinites, basalts, trachybasalts) and intermediate-felsic (e.g. phonolites, trachytes, rhyolites), and these silica-subsaturated alkaline volcanic rocks, which never show free quartz (Schmincke and Sumita 2010). Quartz was found in the airborne samples during dust events, while opal $\left(\mathrm{SiO}_{2} \cdot \mathrm{nH}_{2} \mathrm{O}\right.$ meanly biogenic) was mostly found in seawater samples. Opal frequently showed laminar structures or evident biological structures such as spicules (Fig. 9). The increase of calcium-magnesium carbonates in sediment trap samples could be explained by the high biogenic contribution in the water column.

Crystalline hematite and goethite were the predominant forms of iron oxides present in Saharan dust, as previously observed (Klaver et al. 2011). The mean primary origin of these iron oxy-hydroxide particles can be related to the maphic volcanic rocks and the BIFs of the Precambrian crystalline basement in the Western Sahara and Mauritania area (Rocci et al. 1991, Lehbib et al. 2009). These iron formations contain magnetite, hematite and goethite, and these iron minerals may reach $75 \%$ in rock total volume, with fine-grained textures and size particles below $1 \mathrm{~mm}$ (Lehbib et al. 2009). The estimation of the hematite/ goethite ratio (Lázaro et al. 2008) of Saharan dust at Gran Canaria Island using optical methods (reflectance spectroscopy) showed a range between 0.3 and 0.6. Therefore, the higher density of Fe oxy-hydroxides should lead them to sink faster. Therefore, the anomalous high concentration of this mineral at $150 \mathrm{~m}$ depth (Fig. 7) is rather difficult to explain using classical patterns of gravitational settling.

The selective concentration pattern of iron particles could be explained by biological retention processes in the water column. Several studies have shown that phagotrophic flagellates could ingest even micrometric iron particles or colloids, dissolving and regenerating some types of particulate iron during digestion (Barbeau et al. 1996, Chase and Price 1998, Barbeau and Moffett 2000), and retaining the mineral in the water column (Nodwell and Price 2001). Moreover, it has been suggested that colony formation in Trichodesmium is an adaptive strategy to trap the dust and enhance iron acquisition (Rubin 2011), dissolving dust and oxides. It is also known that unicellular dinitrogen fixing cyanobacteria produce two to three orders of magnitude more extracellular polysaccharides (EPS) than other phytoplankton (Sohm 2011). This behaviour could help to retain iron in the upper layers of the ocean, favouring cyanobacteria during dust events. Benavides et al. (2013) observed that $66 \%$ of unicellular diazotrophs were attached to organic particles after a dust event. Whether the iron is ingested by protists, trapped by Trichodesmium colonies, or simply attached to organic particles through EPS, the iron retention in aggregates (Fig. 9A, E) seems to be the explanation for its higher proportion in comparison with other minerals in the mixed layer. This iron retention suggests an evolutionary adaptation of marine microorganisms to using limiting micronutrients in the ocean, and could explain the ability of many autotrophs and mixotrophs (e.g. dinoflagellates) to build aggregations.

\section{CONCLUSIONS}

The image particle analysis and the SEM-EDX mineralogy determination used to calculate the airborne concentration and the lithogenic fluxes are one of the innovations of this research. These techniques could complement the widely used lithogenic determination through biogenic mass elimination by acid digestion. It has been demonstrated that in this classical determination, around $10-30 \%$ of the carbonate fraction of the lithogenic mass may be lost (Fig. 5).

On the other hand, the AR and IC indexes were not a good proxy to differentiate dust or non-dust events. No significant differences were found in any type of sample between morphometric indexes in dust events particles in comparison with non-dust events particles. The dust events analysed in this study, which originated in northern Mauritania/the Western Sahara, showed a mean size of coarse silt of $37 \mathrm{~mm}$. Grain size and particle concentration were higher at 10 and $150 \mathrm{~m}$ depth than in airborne samples, and were higher during dust events than during non-dust events for all samples (except at $150 \mathrm{~m}$ depth).

The concentration of illite and quartz particles was lower in lithogenic than in airborne samples, whereas the concentration of iron oxy-hydroxide particles (hematite and goethite) was higher in lithogenic particles. This anomalous retention of denser minerals could reveal the biological interaction of iron particles with microorganisms described by some authors (Nodwell and Price 2001, Sohm 2011, Benavides et al. 2013). Under the sedimentological point of view, this anomalous "low sinking behaviour" of the densest iron oxyhydroxide particles is another innovation presented in this research.

The airborne particles cited in this work (mainly quartz, illite, hematite, goethite, $\mathrm{Ca}-\mathrm{Mg}$ carbonate and opal) were associated with sediments from the northern Mauritania and the Western Sahara, with two sources: particles from erosion of the Precambrian shield, the Paleozoic and Post-Paleozoic belt (iron oxides and silicates); and particles of organic origin from soils and desiccated lakes (carbonates and diatoms skeletons).

\section{ACKNOWLEDGEMENTS}

This study was partially funded by the projects "Mafia" (CTM2012-39587) and "Lucifer" (CTM200803538) of the Spanish Government, and the project PI2007/042 of the Canary Islands Government. Our thanks to Lidia Nieves for her valuable work and to the people involved in the cruises carried out to collect samples.

\section{REFERENCES}

Alonso-González I., Arístegui J., Lee C., et al. 2010a. Role of slowly settling particles in the ocean carbon cycle. Geophys. Res. Lett. 37: L13608. 
http://dx.doi.org/10.1029/2010g1043827

Alonso-González I., Arístegui J., Lee C., et al. 2010b. Regional and temporal variability of sinking organic matter in the subtropical northeast Atlantic Ocean: a biomarker diagnosis. Biogeosciences 7: 2101-2115.

http://dx.doi.org/10.5194/bg-7-2101-2010

Baker A., Jickells T. 2006. Mineral particle size as a control on aerosol iron solubility. Geophys. Res. Lett. 33: L17608. http://dx.doi.org/10.1029/2006gl026557

Barbeau K., Moffett J. 2000. Laboratory and field studies of colloidal iron oxide dissolution as mediated by phagotrophy and photolysis. Limnol. Oceanogr. 45: 827-835. http://dx.doi.org/10.4319/lo.2000.45.4.0827

Barbeau K., Moffett J., Caron D., et al. 1996. Role of protozoan grazing in relieving iron limitation of phytoplankton. Nature 380: 61-64. http://dx.doi.org/10.1038/380061a0

Barcelona Supercomputing Center. 2011. BSC.es. (n.d.). Mineral Dust [BSC-CNS. [online] Available at: http://www.bsc.es/ earth-sciences/mineral-dust-forecast-system [Accessed $27 \mathrm{Mar}$ and 3 Apr. 2011].

Benavides M., Arístegui J., Agawin N., et al. 2013. Enhancement of nitrogen fixation rates by unicellular diazotrophs vs. Trichodesmium after a dust deposition event in the Canary Islands. Limnol. Oceanogr. 58: 267-275. http://dx.doi.org/10.4319/lo.2013.58.1.0267

Blott S., Pye K. 2001. Gradistat: A grain size distribution and statistics package for the analysis of unconsolidated sediments. Earth Surf. Process. Landforms 26: 1237-1248. http://dx.doi.org/10.1002/esp.261

Blott S., Pye K. 2008. Particle shape: A review and new methods of characterization and classification. Sedimentology 55: 31-63.

Bory A., Dulac F., Moulin C., et al. 2002. Atmospheric and oceanic dust fluxes in the northeastern tropical Atlantic Ocean: How close a coupling? Ann. Geophys. 20: 2067-2076. http://dx.doi.org/10.5194/angeo-20-2067-2002

Bronne G., Chauve J.J. 1979. Precambrian banded iron-formations of the Ijil Group (Kediat Ijil, Reguibat Shield, Mauritania). Econ. Geol. 74: 77-94.

Brust J., Waniek J. 2010. Atmospheric dust contribution to deep-sea particle fluxes in the subtropical Northeast Atlantic. Deep-Sea Res. Part I 57: 988-998. http://dx.doi.org/10.1016/j.dsr.2010.04.011

Brust J., Schulz-Bull D., Leipe T., et al. 2011. Descending particles: From the atmosphere to the deep ocean-A time series study in the subtropical NE Atlantic. Geophys. Res. Lett. 38: L06603. http://dx.doi.org/10.1029/2010g1045399

Chase Z., Price N.M. 1998. Metabolic consequences of iron deficiency in heterotrophic marine protozoa. Limnol. Oceanogr. 42: 1673-1684.

De la Rocha C., Passow U. 2007. Factors influencing the sinking of POC and the efficiency of the biological carbon pump. DeepSea Res. Part II 54: 639-658. http://dx.doi.org/10.1016/j.dsr2.2007.01.004

Delgado J. 2010. Origin and SEM analysis of aerosols in the high mountain of Tenerife (Canary Islands). Engineering 2: 1119-1129. http://dx.doi.org/10.4236/ns.2010.210139

Ersoy O. 2010. Surface area and volume measurements of volcanic ash particles by SEM stereoscopic imaging. J. Volcanol. Geotherm. Res. 190: 290-296. http://dx.doi.org/10.1016/j.jvolgeores.2009.12.006

Fahl K., Nöthig, E. 2007. Lithogenic and biogenic particle fluxes on the Lomonosov Ridge (central Arctic Ocean) and their relevance for sediment accumulation: Vertical vs. lateral transport. Deep-Sea Res. Part I 54: 1256-1272. http://dx.doi.org/10.1016/j.dsr.2007.04.014

Gelado-Caballero M., López-García P., Prieto S., et al. 2012. Longterm aerosol measurements in Gran Canaria, Canary Islands: Particle concentration, sources and elemental composition. J. Geophys. Res. D: 117.

González-Dávila M., Santana-Casiano M., Millero F. 2005. Oxidation of iron (II) nanomolar with $\mathrm{H}_{2} \mathrm{O}_{2}$ in sea water. Geochim. Cosmochim. Acta 69: 83-93 http://dx.doi.org/10.1016/j.gca.2004.05.043

Goossens D. 2005. Quantification of the dry aeolian deposition of dust on horizontal surfaces: An experimental comparison of theory and measurements. Sedimentology 52: 859-873. http://dx.doi.org/10.1111/j.1365-3091.2005.00719.x

Goudie A., Middleton N. 2001. Saharan dust storms: Nature and consequences. Earth-Sci. Rev. 56: 179-204.

http://dx doi.org/10.1016/S0012-8252(01)00067-8

Henderiks J., Freudenthal T., Meggers H., et al. 2002. Glacial-interglacial variability of particle accumulation in the Canary Basin: A time-slice approach. Deep-Sea Res. Part II 49: 3675-3705. http://dx.doi.org/10.1016/S0967-0645(02)00102-9

Hurlbut C., Sharp W. 1998. Dana's minerals and who to study them. 4th ed. John Wiley and Sons, Inc., 328 pp.

Iwamoto Y., Yumimoto K., Toratani M., et al. 2011. Biogeochemical implications of increased mineral particle concentrations in surface waters of the northwestern North Pacific during an Asian dust event. Geophys. Res. Lett. 38: L01604. http://dx.doi.org/10.1029/2010g1045906

Jickells T., An Z., Andersen K., et al. 2005. Global iron connections between desert dust, ocean biogeochemistry, and climate. Science 308: 67-71. http://dx.doi.org/10.1126/science.1105959

Journet E., Desboeufs K., Caquineau S., et al. 2008. Mineralogy as a critical factor of dust iron solubility. Geophys. Res. Lett. 35: L07805 http://dx.doi.org/10.1029/2007g1031589

Kaufman Y., Tanré D., Boucher O. 2002. A satellite view of aerosols in the climate system. Nature 419: 215-223. http://dx.doi.org/10.1038/nature01091

Klaver A., Formenti P., Caquineau S., et al. 2011. Physico-chemical and optical properties of sahelian and saharan mineral dust: In situ measurements during the gerbils campaign. Q.J.R. Meteorol. Soc. 137: 1193-1210. http://dx.doi.org/10.1002/qj.889

Lázaro F., Gutiérrez L., Barrón V., et al. 2008. The speciation of iron in desert dust collected in Gran Canaria (Canary Islands): Combined chemical, magnetic and optical analysis. Atmos. Environ. 42: 8987-8996. http://dx.doi.org/10.1016/j.atmosenv.2008.09.035

Lehbib S., Arribas A., Melgarejo J. 2009. Depósitos de Hierro de Tipo BIF en la Región del Tiris, Sáhara Occidental. Macla 11: 111-112

Levine I. 2001. Physical Chemistry (5th ed.). McGraw-Hill, Boston. ISBN 978-0072534955. $955 \mathrm{pp}$

Lide D. 1996. Handbook of chemistry and Physics. CRC Press. Special student edition. 77 ed., 2608 pp.

Mahowald N., Engelstaedter S., Luo C., et al. 2009. Atmospheric iron deposition: global distribution, variability, and human perturbations. Ann. Rev. Mar. Sci. 1: 245-278. http://dx.doi.org/10.1146/annurev.marine.010908.163727

Menéndez I., Díaz-Hernández J., Mangas J., et al. 2007. Airborne dust accumulation and soil development in the North-East sector of Gran Canaria (Canary Islands, Spain). J. Arid Environ. 71: $57-81$. http://dx.doi.org/10.1016/j.jaridenv.2007.03.011

Menéndez I., Derbyshire E., Engelbrecht J., et al. 2009. Saharan dust and the aerosols on the Canary Islands: past and present. In: Cheng M., Liu W. (eds.), Airborne Particulates. Nova Science Publisher, New York, 39-80 pp

Mills M., Ridame C., Davey M., et al. 2004. Iron and phosphorus co-limit nitrogen fixation in the eastern tropical North Atlantic. Nature 429: 292-294. http://dx.doi.org/10.1038/nature02550

Neuer S., Torres-Padrón M., Gelado-Caballero M., et al. 2004. Dust deposition pulses to the eastern subtropical North Atlantic gyre: Does ocean's biogeochemistry respond? Global Biogeochem. Cycles 18: 1-10. http://dx.doi.org/10.1029/2004GB002228

Nodwell L., Price N. 2001. Direct use of inorganic colloidal iron by marine mixotrophic phytoplankton. Limnol. Oceanogr. 46: 765-777. http://dx.doi.org/10,4319/1o.2001.46.4.0765

Okada K., Heintzenberg J., Kai K., et al. 2001. Shape of atmospheric mineral particles collected in three Chinese arid-regions. Geophys. Res. Lett. 28: 3123-3126. http://dx.doi.org/10.1029/2000GL012798

Parekh P., Joos F., Müller S.A. 2008. Modeling assessment of the interplay between aeolian iron fluxes and iron-binding ligands in controlling carbon dioxide fluctuations during Antarctic warm events. Paleoceanography 23: PA4202. http://dx.doi.org/10.1029/2007PA001531

Prospero J., Carlson T. 1980. Saharan air outbreaks over the tropical North Atlantic. Pure Appl Geophys. 119: 677-691. http://dx.doi.org/10.1007/BF00878167

Ratmeyer V., Balzer W., Bergametti G., et al. 1999. Seasonal im- 
pact of mineral dust on deep-ocean particle flux in the eastern subtropical Atlantic Ocean. Mar. Geol. 159: 241-252. http://dx.doi.org/10.1016/S0025-3227(98)00197-2

Rawle A. 2003. Basic principles of particle-size analysis. Surf. Coat. Int. 86: 58-65.

Red de Control y Vigilancia de la Calidad del Aire de Canarias. 2011. Formulario de datos históricos. Gobiernodecanarias.org. Retrieved March and April 2011, Database available in: http://www.gobiernodecanarias.org/medioambiente/calidaddelaire/datosHistoricosForm.do

Reid E., Reid J., Meier M., et al. 2003. Characterization of African dust transported to Puerto Rico by individual particle and size segregated bulk analysis. J. Geophys. Res. D. 108: 8591. http://dx.doi.org/10.1029/2002JD002935

Rocci G., Bronner G., Deschamps M. 1991. Crystalline basement of the West Africa Craton. In: Dallmeyer R. and Lecorche J. (eds) The West African Orogens and Circum-Atlantic Correlatives. Springer, Berlin, 31-61. http://dx.doi.org/10.1007/978-3-642-84153-8 3

Rubin M. 2011. Dust- and mineral-iron utilization by the marine dinitrogen-fixer Trichodesmium. Nat. Geosci. 4: 529-534. http://dx.doi.org/10.1038/ngeo1181

Sahara Airmass Outbreak Model. 2011- HYSPLIT - Hybrid Single Particle Lagrangian Integrated Trajectory model. Hysplit.uhu. es. Retrieved March and April 2011, from: http://www.hysplit.uhu.es/hysplit_sa.php

Scheuvens D., Schütz L., Kandler K., et al. 2013. Bulk composition of northern African dust and its source sediments - A compilation. Earth-Sci. Rev. 116: 170-194. http://dx.doi.org/10.1016/j.earscirev.2012.08.005

Schmincke H., Sumita M. 2010. Geological evolution of the Canary Islands: a young volcanic archipelago adjacent to the old Afri- can Continent. Ed. Görres, Koblenz. 200 pp.

Shi Z., Bonneville S., Krom M.D., et al. 2011. Iron dissolution kinetics of mineral dust at low $\mathrm{pH}$ during simulated atmospheric processing. Atmos. Chem. Phys. 11: 995-1007. http://dx.doi.org/10.5194/acp-11-995-2011

Shi Z., Krom M., Jickells T., et al. 2012. Impacts on iron solubility in the mineral dust by processes in the source region and the atmosphere: A review. Aeolian Res. 5: 21-42. http://dx.doi.org/10.1016/j.aeolia.2012.03.001

Sohm J. 2011. Nitrogen fixation by Trichodesmium spp. and unicellular diazotrophs in the North Pacific Subtropical Gyre. J. Geophys. Res.-Biogeo. 116.

Soulaimani A., Burkhard M. 2008. The Anti-Atlas chain (Moroc$\mathrm{co})$ : the southern margin of the Variscan belt along the edge of the West African Craton. Geol. Soc. London Spec. Publ. 297: 433-452. http://dx.doi.org/10.1144/SP297.20

Torres O., Bhartia P.K., Herman J.R., et al. 2002. A long-term record of aerosol optical depth from TOMS observations and comparison to AERONET measurements. J. Atmos. Sci. 59: 398-413.

http://dx.doi.org/10.1175/1520-0469(2002)059<0398:ALTRO $\mathrm{A}>2.0 . \mathrm{CO} ; 2$

Wilson S., Steinberg D., Buesseler K. 2008. Changes in fecal pellet characteristics with depth as indicators of zooplankton repackaging of particles in the mesopelagic zone of the subtropical and subarctic North Pacific Ocean. Deep-Sea Res. Part II 55: 1636-1647. http://dx.doi.org/10.1016/j.dsr2.2008.04.019

Zingg T. 1935. Beitrag zur Schotteranalyse. Mineral. Petrogr. 15: 39-140. 